\title{
Studies on Genetic Variability, Heritability and Genetic Advance in Garden Pea (Pisum sativum L.) varieties
}

\author{
T. N. Vijaya Kumar ${ }^{1 *}$, T. B. Alloli², H. P. Hadimani ${ }^{2}$, P. S.Ajjappalavar ${ }^{3}$, \\ D. Satish ${ }^{2}$, Abdul Kareem ${ }^{3}$ and C. N. Hanchinamani ${ }^{1}$ \\ ${ }^{1}$ K. R. C College of Horticulture, Arabhavi- 591218, Karnataka, India \\ ${ }^{2}$ College of Horticulture, Bagalkot- 587104, Karnataka, India \\ ${ }^{3}$ Horticultural Research Station Devihosur-581 110, Karnataka, India
}

*Corresponding author

\section{A B S T R A C T}

\section{Keywords}

Leguminosae

(Fabaceae) family, white flowered, garden pea, sweet pea

\section{Article Info}

Accepted:

04 November 2019

Available Online:

10 December 2019
An Experiment was carried out at Kittur Rani Channamma College of Horticulture, Arabhavi, UHS, Bagalkot during the year 2018-19.The observations were recorded on various yield and yield contributing characters. Analysis of variance indicated highly significant difference among the genotypes for all the characters indicating the presence of wide range of variability in the genotypes. ThePCV was invariably higher than their corresponding GCV for all the characters. High GCV as well as PCV wasobservedfornumber of branches per plant (25.55 and 27.46), pod yield per plant (23.42 and 23.64) and pod yield per plot (23.12 and 23.68) and indicates the existence of broad genetic base. High heritability coupled with high genetic advance over percent mean observed for the traits viz., plant height, number of branches per plant, number of leaves per plant,number of pods per plant, number of pods per axil, pod length, pod yield per plant, pod yield per plot, number of seeds per pod, weight of 100 seeds, protein and TSS. These characters are under the influence of additive gene actionand selection for genotypic and phenotypic improvement for these traits would be effective.

\section{Introduction}

A member of Leguminosae (Fabaceae) family and the famous plant species in which G.H. Mendel worked out Mendel's Law and Genetic principles. It is the second most important food legume worldwide after
Phaseolus vulgaris (Taranet al.,2005).It is grown mainly as a winter vegetable in the plains of North India and as a summer vegetable in the hills of other states (Thamburaj, 2015). Pea is of Mediterranean origin, and the Near East and Ethiopia are considered as secondary centres of origin 
(Blixt, 1974). Peas are highly nutritive and are rich source of digestible proteins (7\%) along with carbohydrates and minerals. There are two sub species, namely Pisum arvens known as field pea, which produce coloured flowers and Pisum sativum, the white flowered, horticultural or garden pea also known as sweet pea.

Success of any breeding programme for its improvement depends on the existing genetic variability in the base population and on the efficiency of selection (Kumari et al., 2008). Heritability indicates the proportion of phenotypic variance that is due to genotypes which is heritable. It serves as a useful guide to breeders as the selection for trait having high heritability. It will be effective and improvement will be brought through selection. The genetic advance is an improvement in the genetic value of new population as compared to original one. It will be possible to decide various breeding programmes for improvement of different characters based on the study of heritability and genetic advance (Kumari et al., 2012).Hence, the present investigation is carried out for various economic traits and to measure the extent of variability, heritability, genetic advance and their genetic makeup in garden peas.

\section{Materials and Methods}

The experiment was carried out at research block of department of Vegetable Science at Kittur Rani Channamma College of Horticulture, Arabhavi, Belagavi district (Karnataka), UHS, Bagalkot during 20182019.The experimental material comprised of twenty genotypes including check, which were collected from different source (Table 1).

The experiment was laid out in Randomized complete block design (RCBD) design with three replications. The treatments or genotypes were randomly assigned in each replication. The whole investigation was done under the scientific management practices.During study, observations for plant height $(\mathrm{cm})$, number of primary branches per plant, number of leaves per plant, days to first flowering, days to $50 \%$ flowering, days to first picking, number of pods per plant, number of axil per plant,pod length $(\mathrm{cm})$, pod width $(\mathrm{cm})$,number of seeds per pod, weight of 100 seeds, pod yield per plant (g), pod yield per plot, T.S.S and protein (Alikhan, 1973) were recorded on five randomly selected plants from each treatment.

The genotypic and phenotypic coefficients of variation were calculated as per the method was suggested by Burton and Devane (1953). Heritability in broad sense and expected genetic advance on the basis of percent of mean were worked out according to the method advocated by Robinson et al., (1953) and Johnson et al., (1955), respectively.

\section{Results and Discussion}

The analysis of variance (Table 1) revealed that highly significant (both at $\mathrm{p}=0.01$ and $p=0.05$ ) variation among the genotypes for growth, yield and quality parameters in garden pea. It is indicated that, sufficient genetic variability present in the garden pea genotypes for various characters studied hence, considerable crop improvement can be achieved.

With a view to understand the extent to which the observed variations are due to genetic factors, the range, mean, phenotypic variance $(\mathrm{PV})$, genotypic variance $(\mathrm{GV})$, phenotypic coefficient of variation (PCV), genotypic coefficient of variation (GCV), broad sense heritability $\left(\mathrm{h}^{2}\right)$, genetic advance (GA) and genetic advance as per cent of mean (GAM) were worked out and are presented in Table 3. The data revealed that, existence of large 
amount of variability to most of the characters studied.

The mean values of various genotypes has also showed wide range of variability for various characters, which were studied in present investigation (Table 3). The range record forplant height (46.66-83.13), number of primary branches per plant (1.40-3.16), number of leaves per plant (37.26-90.46), days to first flowering (39.53-54.60), days to $50 \%$ flowering (44.66-60.66), days to first picking (60.33-75.66), number of pods per plant (18.38-33.73), number of axil per plant (1.002.00), pod length (5.73-10.44), pod width (0.91-1.42), number of seeds per pod (5.139.33), weight of 100 seeds (27.72-46.59), pod yield per plant (88.77-228.95), pod yield per plot (3.53-9.15), protein (18.39-27.26) and T.S.S (7.10-13.16).

Phenotypic coefficient of variation (PCV) were higher in magnitude than the corresponding genotypic coefficient of variation $(\mathrm{GCV})$ for all the characters studied in present investigation which indicated, noticeable variability in the used genetic material which was not only due to genotypic effect but also due to the effect of environment. Hence, care has to be taken in making selection for these traits on the basis of phenotypic performance alone. Iqbal et al., (2015), Gudadinniet al., (2017), Pandeyet al., (2017), Barcchiyaet al., (2018),Katochet al., (2016), were also recorded similar observations in their study.

In the present study, high GCV and PCV were observed for number of branches per plant, pod yield per plant and pod yield per plot. It indicates the existence of broad genetic base, which would be amenable for further selection. The similar results were also observed byPal and Singh (2012), Pandey et al., (2015), Saxena et al., (2014), Gudadiniet al., (2017), Kumar et al., (2015) and Katochet al., (2016).

Moderate GCV and PCV were observed for plant height, number of pods per plant, pod length, number of seeds per pod, weight of 100 seeds, protein and TSS level of seeds. This implied equal importance of additive and non additive gene action in these characters.

These results are in accordance with results ofBarcchiyaet al., (2018), Gudadiniet al., (2017), Thakur et al., (2016), Chaudhary and Sharma (2003).

Low GCV and PCV were observed for days to $50 \%$ flowering, days to first flowering, days to first picking and pod width. This indicates the narrow genetic baseexistence. These results are in conformity with the results ofPal and Singh (2012),Jaiswal et al., (2013), Katochet al., (2016),

Coefficient of variation indicates only the extent of variability present in genotypes for different traits, but for the prediction of response to selection heritability estimates are useful. High broad sense heritability (> 60\%) was observed for plant height, number of branches per plant, number of leaves per plant,days to first flowering, days to $50 \%$ flowering, days to first picking, number of pods per plant, number of pods per axil, pod length, pod width, pod yield per plant, pod yield per plot, number of seeds per pod, weight of 100 seeds, protein and TSS.Heritability is the fundamental in practicability of selection, because it act as predictive instrument in expressing the variability of phenotypic value as guide to breeding value. Similar results were also obtained by Jaiswal et al., (2013),Barcchiyaet al., (2018), Ceyhan et al., (2012),Georieraet al., (2016), Thakur et al., (2016),Katochet al., (2016),Pal and Singh (2012). 
Table.1 Details of garden pea genotypes used in the experiment

\begin{tabular}{|l|l|l|}
\hline Sl. No. & Genotypes & Source \\
\hline $\mathbf{1}$ & PS-10 & Collection from West Bengal (Cooch behar) \\
\hline $\mathbf{2}$ & NP-20 & Collection from West Bengal (Cooch behar) \\
\hline $\mathbf{3}$ & Goldie & Collection from West Bengal (Cooch behar) \\
\hline $\mathbf{4}$ & Taj C3 & Collection from West Bengal (Cooch behar) \\
\hline $\mathbf{5}$ & KSP-110 & Collection from West Bengal (Cooch behar) \\
\hline $\mathbf{6}$ & PAN 4009 & Collection from West Bengal (Alipurduar) \\
\hline $\mathbf{7}$ & GS-10 & Collection from Madhya Pradesh (Jabalpur) \\
\hline $\mathbf{8}$ & Super arkel & Collection from Madhya Pradesh(Jabalpur) \\
\hline $\mathbf{9}$ & Jindal-10 & Collection from Madhya Pradesh (Mandsaur) \\
\hline $\mathbf{1 0}$ & VBL-10 & Collection from Maharashtra (Sangli) \\
\hline $\mathbf{1 1}$ & HUB-1 & Collection from Belagavi \\
\hline $\mathbf{1 2}$ & HUB-2 & Collection from Belagavi \\
\hline $\mathbf{1 3}$ & Punjab-89 & Collection from Madhya Pradesh (Mandsaur) \\
\hline $\mathbf{1 4}$ & HUB-3 & Collection from Belagavi \\
\hline $\mathbf{1 5}$ & HUB-4 & Collection from Maharashtra (Kollapur) \\
\hline $\mathbf{1 6}$ & HUB-5 & Collection from Maharashtra (Kollapur) \\
\hline $\mathbf{1 7}$ & HUB-6 & Collection from Belagavi \\
\hline $\mathbf{1 8}$ & HUB-7 & Collection from Bidar \\
\hline $\mathbf{1 9}$ & HUB-8 & Collection from Bidar \\
\hline $\mathbf{2 0}$ & Arka Priya & IIHR, Hesaragatta \\
\hline
\end{tabular}

Table.2 Analysis of variance (mean sum of squares) for growth, earliness, yield and duality parameters in garden pea.

\begin{tabular}{|l|l|c|c|c|}
\hline SI. No. & Traits & Replications & Genotypes & Error \\
\hline $\mathbf{1}$ & Plant Height $(\mathrm{cm})$ & 0.41 & $317.48^{* *}$ & 11.46 \\
\hline $\mathbf{2}$ & Number of branches per plant & 0.03 & $1.05^{* *}$ & 0.05 \\
\hline $\mathbf{3}$ & Number of leaves per plant & 2.08 & $447.59^{* *}$ & 9.97 \\
\hline $\mathbf{4}$ & Days to first flowering & 8.94 & $56.24^{* *}$ & 6.69 \\
\hline $\mathbf{5}$ & Days to 50\% flowering & 6.71 & $58.62^{* *}$ & 7.34 \\
\hline $\mathbf{6}$ & Days to first picking & 1.85 & $55.17^{* *}$ & 4.93 \\
\hline $\mathbf{7}$ & Number of pods per plant & 1.17 & $41.59^{* *}$ & 2.16 \\
\hline $\mathbf{8}$ & Number of pods per axil & 0.004 & $0.39^{* *}$ & 0.008 \\
\hline $\mathbf{9}$ & Pod length $(\mathrm{cm})$ & 0.02 & $3.97^{* *}$ & 0.18 \\
\hline $\mathbf{1 0}$ & Pod width $(\mathrm{cm})$ & 0.001 & $0.043^{* *}$ & 0.003 \\
\hline $\mathbf{1 1}$ & Pod yield per plant $(\mathrm{g})$ & 2.06 & $4368.74^{* *}$ & 27.52 \\
\hline $\mathbf{1 2}$ & Pod yield per plot $(\mathrm{kg})$ & 0.01 & $6.89^{* *}$ & 0.11 \\
\hline $\mathbf{1 3}$ & Number of seeds per pod & 0.001 & $3.10^{* *}$ & 0.12 \\
\hline $\mathbf{1 4}$ & Weight of 100 seeds $(\mathrm{g})$ & 1.23 & $75.58^{* *}$ & 3.95 \\
\hline $\mathbf{1 5}$ & Protein content $(\%)$ & 0.01 & $24.19^{* *}$ & 0.21 \\
\hline $\mathbf{1 6}$ & TSS $\left({ }^{0} \mathrm{~B}\right)$ & 0.11 & $8.10^{* *}$ & 0.08 \\
\hline
\end{tabular}

** Significance at $1 \% \quad *$ Significance at $5 \%$ 
Table.3 Estimates of genetic parameters for growth, earliness, yield and quality parameters in garden pea genotypes

\begin{tabular}{|c|c|c|c|c|c|c|c|c|}
\hline $\begin{array}{l}\text { Sl. } \\
\text { No. }\end{array}$ & Traits & Mean & Range & $\begin{array}{l}\text { GCV } \\
(\%)\end{array}$ & $\begin{array}{l}\text { PCV } \\
(\%)\end{array}$ & $\begin{array}{l}h^{2}(b s) \\
(\%)\end{array}$ & GA & $\begin{array}{l}\text { GAM } \\
(\%)\end{array}$ \\
\hline 1 & Plant Height $(\mathrm{cm})$ & 61.65 & $46.66-83.13$ & 16.38 & 17.27 & 89.90 & 19.72 & 31.99 \\
\hline 2 & Number of branches per plant & 2.25 & $1.40-3.16$ & 25.55 & 27.46 & 86.56 & 1.10 & 48.98 \\
\hline 3 & Number of leaves per plant & 61.52 & $37.26-90.46$ & 19.63 & 20.29 & 93.60 & 24.07 & 39.12 \\
\hline 4 & Days to first flowering & 49.73 & $39.53-54.60$ & 8.17 & 9.68 & 71.17 & 7.06 & 14.19 \\
\hline 5 & Days to $50 \%$ flowering & 55.58 & $44.66-60.66$ & 7.43 & 8.89 & 69.94 & 7.12 & 12.81 \\
\hline 6 & Days to first picking & 70.35 & $60.33-75.66$ & 5.81 & 6.61 & 77.23 & 7.40 & 10.53 \\
\hline 7 & Number of pods per plant & 23.76 & $18.38-33.73$ & 15.25 & 16.46 & 85.86 & 6.91 & 29.11 \\
\hline 8 & Number of pods per axil & 1.83 & $1.00-2.00$ & 19.57 & 20.23 & 93.55 & 0.71 & 38.99 \\
\hline 9 & Pod length $(\mathrm{cm})$ & 8.61 & $5.73-10.44$ & 13.04 & 13.98 & 86.99 & 2.15 & 25.05 \\
\hline 10 & Pod width $(\mathrm{cm})$ & 1.32 & $0.91-1.42$ & 8.67 & 9.76 & 78.83 & 0.21 & 15.86 \\
\hline 11 & Pod yield per plant (g) & 162.38 & $88.77-228.95$ & 23.42 & 23.64 & 98.13 & 77.62 & 47.80 \\
\hline 12 & Pod yield per plot $(\mathrm{kg})$ & 6.50 & $3.53-9.15$ & 23.12 & 23.68 & 95.34 & 3.02 & 46.51 \\
\hline 13 & Number of seeds per pod & 7.15 & $5.13-9.33$ & 13.92 & 14.80 & 88.51 & 1.93 & 26.99 \\
\hline 14 & Weight of 100 seeds (g) & 39.51 & $27.72-46.59$ & 12.36 & 13.35 & 85.79 & 9.32 & 23.59 \\
\hline 15 & Protein content $(\%)$ & 23.68 & $18.39-27.26$ & 11.93 & 12.09 & 97.39 & 5.74 & 24.27 \\
\hline 16 & $\operatorname{TSS}\left({ }^{0} \mathrm{~B}\right)$ & 9.96 & $7.10-13.16$ & 16.40 & 16.66 & 96.88 & 3.31 & 33.26 \\
\hline
\end{tabular}

The very high estimates of heritability coupled with high values of genetic advance over per cent mean were observed for traits such asplant height, number of branches per plant, number of leaves per plant,number of pods per plant, number of pods per axil, pod length, pod yield per plant, pod yield per plot, number of seeds per pod, weight of 100 seeds, protein and TSS. These characters are under the influence of additive gene action. These results are in accordance with the findings of Gudadiniet al., (2017),Pandey et al., (2017), Nawab et al., (2008), Thakur et al., (2016),Fikreselassie (2012),Georgieva et al., (2016).

High degree of additive components like high estimates of heritability coupled with high GAM and presence of high GCV and PCV were obtained for the characters likenumber of branches per plant, number of leaves per plant, number of pods per axil, pod yield per plant and pod yield per plot, it indicates in garden pea genetic improvement can be achieve through selection by using the existing germplasms for above characters.

\section{References}

Ali-khan, S. T. and Youngs, C. G., 1973, Variation in protein content in field pea. Can. J. Plant Sci., 53: 37-41.

Barcchiya, J.,Naidu, A. K., Mehta, A. K. and Upadhyay, A., 2018, Genetic variability, heritability and genetic advance for yield and yield components in pea (Pisum sativum L.). International Journal of Chemical Studies., 6(2):3324-3327. 
Blixt, S., 1974, The pea,Hand book of genetics,Plenum Press, New York., 2: p p.181-221.

Burton, G. W. and Devane, E. M., 1953, Estimating heritability from replicated clonal material. Agron. J., 45: 478-481.

Ceyhan, E., Kahraman, A., Ates, M. K. andKaradas, S. K., 2012, Stability analysis on seed yield and its components of peas. Bulgarian Journal of Agricultural Science.,18 (6): 905-911.

Chaudhary, D. K. and Sharma, R. R., 2003, Genetic variability, correlation and path analysis for green pod yield and its components in garden pea. Indian Journal of Horticulture., 60(3): 251256.

Fikreselassie, M., 2012, Variability, heritability and association of some morpho-agronomic traits in field pea (Pisun sativum L.) genotypes. Pak. J. Biol. Sci., 15 (8): 358-366.

Georgieva, N., Nikolova, I. and Kosev, V., 2016, Evaluation of genetic divergence and heritability in pea (Pisum sativum L.). Journal of Bioscience and Biotechnology., 5(1): 61-67.

Gudadinni, P., Bahadur, V., Ligade, P., Topno, S. E. and Prasad, V. M., 2017, Study on genetic variability, heritability and genetic advance in garden pea (Pisum sativum var. hortense L.). International Journal of Current Microbiology and Applied Sciences., 6(8): 2384-2391.

Iqbal, M., Bashir, I., Iqbal, M. and Nadeem, K., 2015, Association pattern among yield and its related attributes in peas (Pisum sativumL.). Journal of Agricultural Research., 53(2):173-177.

Jaiswal, N.K., Gupta, A.K., Dewangan, H. and Lavanya, G.R., 2013, Genetic variability analysis in field pea (Pisum sativum L.).Int. J. Sci. and Res., 4 (1): 2006-2007.
Johnson, H. W., Robinson, H. F. and Comstock, R. E., 1955, Estimates of genetic and environmental variability in soyabean. Agron. J.,47: 314-318.

Katoch, V., Singh, P., Devi, M. B., Sharma, A., Sharma, G. D. and Sharma, J. K., 2016, Study of genetic variability, character association, path analysis and selection parameters for heterotic recombinant inbred lines of garden peas (Pisum sativum var. hortense L.) under mid-hill conditions of Himachal Pradesh, India. Legume Research., 39 (2):163-169.

Kumar, R., Kumar, M., Dogra, R. K. and Bharat, N. K., 2015, Variability and character association studies in garden pea (Pisum sativum var. hortense L.) during winter season at mid hills of himachal Pradesh. Legume Research., 38(2): 164-168.

Kumari, A., Kumar, M. and Kohli, U. K., 2008, Genetic Parameters and character association in garden pea (Pisum Sativum L.) cultivars. Vegetable Science., 35(2):160-164.

Kumari, N., Srivastava, J. P., Singh, S. K. and Singh, I. P., 2012, Heritability and genetic advance in vegetable pea (Pisum sativum L.). Annals of Agricultural Sciences., 33(4):244-246.

Nawab, N. N., Subhani, G. M., Qamar, K. M. and Saeed, S. A., 2008, Genetic variability, correlation and path analysis studies in garden pea (Pisum sativum L.). Journal of Agricultural Research., 46(4): 333-340.

Pal, A. K. and Singh, S., 2012,Assessment and genetic variability in garden pea (Pisum sativum L. var. hortense). International Journal of Agricultural Sciences., 7(2):569-573.

Pandey, M., Singh, V. B., Yadav, G. C., Tyagi, N., Vishen, G. S., Bhargav, K. K. and Pandey, P., 2017, Correlation and path coefficient analysis among 
different characters in genotypes of vegetable pea. Vegetable Science., 44 (1): 139-141.

Pandey, P., Singh, N. and Rawat, M., 2015, Study of genetic variation, heritability and correlation in vegetable pea (Pisum sativum L.). The Bioscan., 10(4): 2131-2133.

Robinson, H. F., Comstock, R. E. and Harvery, P. H., 1949, Estimates of heritability and degree of dominance in corn. Agron. J., 41: 353-359.

Saxena, R.R., Vidayakar, V.,Vishkarma, M.V., Yadav, P. S., Meena, M.L. and Lal, G.M., 2014, Genetic variability and heritability analysis for some quantitative traits in field pea (Pisum sativum L.). The Bioscan., 9 (2): 895898.

Taran, B., Zhang, C., Warkentin, T., Tullu, A. and Vanderberg, A., 2005, Genetic diversity among varieties and wild species accessions of pea (Pisum sativum L.) based on molecular markers, morphological and physiological characters. Genome., 48(2): 257.

Thakur, S., Thakur, R.and Mehta, K, D., 2016, Genetic variability and association studies for green pod yield and component horticultural traits in garden pea under high hill dry temperate conditions of Tabo valley of Spiti district of himachal Pradesh. International Journal of Science, Environment and Technology., 5(4):1987-1992.

Thamburaj, S. and Singh, N., 2015, Text book of vegetables, tuber crops and spices. ICAR, New Delhi. pp.196-200.

\section{How to cite this article:}

Vijaya Kumar, T. N., T. B. Alloli, H. P. Hadimani, P. S.Ajjappalavar, D. Satish, Abdul Kareem3 and Hanchinamani, C. N. 2019. Studies on Genetic Variability, Heritability and Genetic Advance in Garden Pea (Pisum sativum L.) varieties. Int.J.Curr.Microbiol.App.Sci. 8(12): 3032-3038. doi: https://doi.org/10.20546/ijcmas.2019.812.353 